\title{
LIST OF MAPS, TABLES AND FIGURES
}

\section{Maps}

1. Part of the former Lebowa, showing locations, landmarks, and farms mentioned in the text

2. The former homeland Lebowa, showing boundaries of pre-1994 magisterial districts

3. The Reef and Pretoria, showing African townships

\section{Tables}

1.1 Northern Sotho speakers living in Reef districts: 1985

1.2 Lebowa women in employment: 1985

3.1 Core songs documented by Huskisson in the 1950s, and still played today

3.2 Additional songs, played by some of the groups met by Huskisson, and still played today

3.3 Additional songs played today, not listed by Huskisson

3.4 Some men's tunes with women's equivalents

5.1 Pedi clothing demarcating life-cycle stages

6.1 Categories of population relocation in South Africa

7.1 Church membership: baditšhaba and majekane

\section{Figures}

I.1 Men's kiba: the regimental song monti. Alexandra Township

I.2 Women's kiba: performing at Funda Centre, Soweto

I.3 Kiba championships held by the Mmino wa setšo Association: judges and performers

I.4 Kiba championships: certificate awarded to members of winning group Ditšhweu tša Malebogo

I.5 Picture of women kiba singers in the government-published Informa

1.1 Programme of annual traditional dance festival, sponsored by the parastatal ESCOM (Electricity Supply Commission), a major employer of black labour

1.2 Members of the SK Alex partner-groups 36

2.1 Elsie Lekgotwane, leading SK Alex in performance 53 
2.2 Andronica Machaba, leading Ditšhweu tša Malebogo in performance

2.3 Ditšhweu ťsa Malebogo in performance 58

2.4 Joanna Maleaka 68

3.1 Dinaka (pipes) resting on the top of a moropa (drum) 73

3.2 Drum belonging to SK Alex being carried from the men's hostel to the piece of open ground where kiba performance takes place

3.3 Harepa player at the Tembisa hostel

3.4 The men and women of Bapedi Champions at the annual party of SK Alex, 1990. Alexandra Township

3.5 Kiba: male dancer performing solo, with pipe players in the background

3.6 SK Alex women: drummer and solo singer in performance

3.7 Nkapile Hlakola, composer/solo singer of Dipalela Tlala, in performance with her group

3.8 A 'diviner' throws the bones: dramatic tableau of Dipalela Tlala

3.9 'Police' making an arrest: dramatic tableau of Dipalela Tlala

3.10 SK Alex on 'home' visits: preparing to depart for, and dancing monti on arriving at, Mamone in Sekhukhune

3.11 Rural women singers performing to greet their urban visitors, SK Alex. Mamone, Sekhukhune

5.1 Female sotho dress of Pedi, showing semabejane or gempe in its pre-initiate and initiate form

5.2 The cyclical succession of initiation regiments in Nchabeleng

5.3 Old sotho dress: Mmagopine dressed up in the garb she wore as an initiate for rainmaking rites

5.4 New sotho dress: Mmagopine in šěse (headscarf), vest, and dituku (waistcloths): Dithabaneng in performance

5.5 Mmagomathumasha Madibane with digempe she wore when first married

5.6 Woman with mekamo hairstyle, Apel, Sekhukhune

5.7 Mmagojane Kgalema dressed in her 'police' outfit:

Dithabaneng in performance 